Reprod. Nutr. Dévelop., 1983, 23 (2 A), 293-301.

\title{
Mortality in premature mice at birth and during neonatal development
}

\author{
Jacqueline LOCTIN, P. DELOST
}

Laboratoire de Physiologie animale, Université de Clermont et ERA CNRS 414 Endocrinologie du Développement, 24, avenue des Landais, B.P. 45, 63170 Aubière, France.

Summary. This paper reports a statistical study of mortality in about 2500 premature mice at birth and during neonatal development. The premature mice were removed by caesarean section and reanimated for $30 \mathrm{~min}$.; surviving mice as well as newborns delivered vaginally on day 20 of pregnancy (control mice) were raised from birth to day 20 by nursing mothers spontaneously delivered at the same time. The mortality rate in the premature mice and control newborns was estimated immediately after birth by caesarean section and $30 \mathrm{~min}$. after reanimation or parturition, $6 \mathrm{~h}$ after birth and at $9 \mathrm{~h}$ every day from neonatal days 2 to 20 . The caesarean section did not cause mortality. The chances of the survival of premature mice at birth depended on both gestational age and birth weight. Premature mice could not survive if their gestational age was less than 19 days and their birth weight less than $33 \%$ of that of newborn mice at term. There was no relationship between mortality and the number of newborns per litter. Two types of mortality were observed in premature mice, mortality at reanimation and breeding mortality. Mortality at reanimation was about $13 \%$; breeding mortality, occurring only during the first 3 neonatal days, was of two types : primary neonatal mortality $(10.9 \%)$, occurring from the end of reanimation up to $6 \mathrm{~h}$ after birth, and secondary neonatal mortality $(6.9 \%)$ which appeared from days 2 to 3 . The role of some factors causing mortality has been discussed.

\section{Introduction.}

The problems of infant prematurity have received much attention from clinicians in the past few years, as evidenced by the extensive literature, and many statistical studies have been reported (Loctin, 1980). Perinatal and neonatal mortality in premature babies is still high (Varangot et al., 1975 ; Fuchs, 1977 ; Rush et al., 1978). Neonatal death occurs essentially before 3 days of age (Hatt et al., 1972 ; Senecal et al., 1977 ; N'Koumoun, 1978); however, there is also low mortality after neonatal day 10 (Rossier, 1969; Laugier and Gold, 1978). Even when additional factors affecting morbidity are present, mortality data related to both birth weight and gestation age are essential for determining the chances of survival of the premature infant (Lubchenco et al., 1972 ; Papiernik, 1977). These results are comparable to those obtained in premature monkey 
(Digiacomo and Shaughnessy, 1972 ; Price et al., 1972 ; Hird et al., 1975 ; Shaughnessy et al., 1978) and premature piglet (Aumaitre et al., 1979).

Except in primates and domestic animals there have been only a few studies concerning prematurity in other species ; thus, nothing is known about mortality in premature rodents. We thought it would be interesting to compare existing data with a rodent model. On the other hand, while some factors involving the mortality of premature neonates have been widely studied, the role of the adrenal cortex remains obscure; in premature humans, results on the adrenal cortex are particularly conflicting. Since the degree to which a premature adrenal cortex functions at birth may be of some importance in determining whether the neonate survives, the mouse seemed to be a good model for studying prematurity because perinatal changes in corticosterone and aldosterone concentrations in mother, foetus and full-term neonate in this species have been studied previously in our laboratory (Dalle et al., 1978). Furthermore, we have recently investigated glucocorticoid and mineralocorticoid functions in premature mice. Finally, since the mouse is a prolific species with short pregnancy and a brief period of postnatal growth, some experiments can be done in premature neonates that are difficult to carry out in other species; for example, it is easy to remove the foetuses by caesarean section (Loctin, 1980).

The aim of the present paper was to make a statistical study of mortality at birth and during neonatal development in premature mice obtained by caesarean section.

\section{Material and methods.}

Animals. - We used primiparous female mice (Swiss $C D_{1}$ strain) of the same age (3 months) and their litters. Male and female mice were caged together overnight from 19 to $7 \mathrm{~h}$, and we called the day a vaginal plug was observed day 1 of pregnancy. The time of mating was known to within $6 \mathrm{~h}$. Pregnant mice were isolated from day 1 in individual cages under controlled conditions of temperature $\left(25 \pm 2{ }^{\circ} \mathrm{C}\right)$ and natural lighting and safeguarded against stress. Breeding results in our laboratory have shown that spontaneous parturition occurs on day 20 of pregnancy in the Swiss $C_{1}$ strain (Loctin, 1980). Premature mice were obtained by caesarean section between 9 and $12 \mathrm{~h}$ on days 18 and 19 of pregnancy.

Caesarean section and reanimation. - Immediately after the dam was decapitated, all the foetuses of the litter were removed by laparotomy $(3 \mathrm{~min}$. for a litter of 6-7 foetuses and $4 \mathrm{~min}$. for a litter of 12-13). The newborn mice were reanimated for $30 \mathrm{~min}$. in a warming box $\left(38^{\circ} \mathrm{C}\right)$ soaked with serum and provided with an oxygen tent.

Raising of neonates. - After respiration and reanimation, premature mice removed by caesarean section on day 19 of pregnancy, as well as newborn mice delivered vaginally on day 20 and taken from their own dam less than $1 \mathrm{~h}$ after parturition, were raised from birth to day 20 by nursing mothers spontaneously delivered at the same time. Only litters from nursing dams which suckled 
newborns immediately after birth and regularly during neonatal development were used in the statistical study of mortality.

Statistical study of mortality. - The study was carried out using about 3400 newborn mice divided into several groups. Mortality was defined as the death of premature mice and control newborns (1) at birth (immediately after caesarean section and $30 \mathrm{~min}$. after reanimation or parturition), (2) $6 \mathrm{~h}$ after birth and (3) at $9 \mathrm{~h}$ every day from neonatal days 2 to 20. The number of dead and the mortality rate were noted at each stage. Only litters with 6-13 newborns were used. To study mortality and body weight at birth and during neonatal development, the litters were pooled then divided into 4 groups each containing : 6-7, 8-9, 10-11 or 12-13 newborns.

Body weight. - The body weight of live premature mice removed by caesarean section on day 19 of pregnancy was estimated $30 \mathrm{~min}$. after reanimation and compared to : (1) newborns delivered vaginally on day 20 and weighed less than $1 \mathrm{~h}$ after parturition, (2) premature mice dying during reanimation. The means \pm SEM are given; Student's t-test was used to calculate probability and significance.

\section{Results.}

\section{Mortality at birth.}

a) After caesarean section. - The mortality rate of 2570 foetuses at the end of caesarean section (133 on day 18, 1986 on day 19 and 451 on day 20 of pregnancy) was $0 \%$; all the foetuses were alive with the thorax moving.

b) Mortality at reanimation (table 1). -- No premature mice with a gestational age of less than 19 days survived when reanimated. Indeed, the mortality rate of 133 foetuses removed by caesarean section on day 18 was $100 \% 30$ min. after reanimation. On the other hand, the number of surviving premature mice was high in newborns removed by caesarean section on day 19 since the mortality rate was only $13.2 \%$. The statistics of this group, based on 1986 premature mice, showed that mortality at reanimation was not a function of the duration of

TABLE 1

Differences in reanimation mortality between foetuses removed by caesarean section at term on day 20 and prematures removed by caesarean section on days 18 and 19 of pregnancy

\begin{tabular}{ccccc}
\hline Groups & $\begin{array}{c}\text { Days } \\
\text { of gestation }\end{array}$ & $\begin{array}{c}\text { Number } \\
\text { of foetuses }\end{array}$ & $\begin{array}{c}\text { Number } \\
\text { dead }\end{array}$ & $\begin{array}{c}\text { Mortality } \\
\text { rate }\end{array}$ \\
\hline Group 1 & day 18 & 133 & 133 & 100 \\
\hline Group 2 & day 19 & 1986 & 262 & 13.2 \\
\hline Group 3 & day 20 & 277 & 4 & 1.4 \\
\hline
\end{tabular}


TABLE 2

Reanimation mortality as a function of the number of newborns per litter of prematures removed by caesarean section on day 19 of pregnancy (Statistics based on 1986 premature mice)

\begin{tabular}{ccccc}
\hline $\begin{array}{c}\text { Number of } \\
\text { newborns per litter }\end{array}$ & $6-7$ & $8-9$ & $10-11$ & $12-13$ \\
\hline Mortality rate & 14.7 & 13.4 & 13.2 & 13.0 \\
\hline
\end{tabular}

caesarean section or the number of foetuses per litter because that rate after reanimation did not vary with the number of foetuses per litter (table 2).

c) Prepartum age and body weight of surviving premature mice (table 3). The mean body weight of newborns delivered vaginally at term on day 20 varied at birth between $1.54 \pm 0.006 \mathrm{~g}$ and $1.59 \pm 0.003 \mathrm{~g}$. In prematures removed by caesarean section on day 18 of gestation and dead after reanimation, mean body weight was $0.91 \pm 0.01 \mathrm{~g}$. In premature mice removed on day 19 , mean body weight after reanimation varied between $1.02 \pm 0.01 \mathrm{~g}$ and $1.07 \pm 0.02 \mathrm{~g}$ in dead prematures and between $1.22 \pm 0.003 \mathrm{~g}$ and $1.26 \pm 0.006 \mathrm{~g}$ in live prematures. Mean body weight of dead premature mice at day 19 of pregnancy

TABLE 3

Difference in body weight $(g)$ as a function of the number of newborns per litter. A comparison between newborn mice delivered vaginally on day 20 and weighed less than $1 \mathrm{~h}$ after birth and premature mice (alive or dead at reanimation) removed by caesarean section on day 19 and weighed 30 min.after reanimation. Values are means \pm SEM. The numbers in parentheses are the number of mice weighed

\begin{tabular}{|c|c|c|c|c|}
\hline Group & $\begin{array}{c}\text { Number } \\
\text { of newborns } \\
\text { per litter }\end{array}$ & $\begin{array}{l}\text { Newborns } \\
\text { delivered vaginally } \\
\text { on day } 20\end{array}$ & $\begin{array}{l}\text { Live } \\
\text { prematures }\end{array}$ & $\begin{array}{c}\text { Dead } \\
\text { prematures }\end{array}$ \\
\hline \multirow{5}{*}{ Group 1} & $12-13$ & $1.48 \pm 0.008(198)$ & $1.20 \pm 0.008$ & $1.07 \pm 0.01(40)$ \\
\hline & $10-11$ & $1.51 \pm 0.009(125)$ & $1.25 \pm 0.01$ & $1.06 \pm 0.08$ \\
\hline & $8-9$ & $1.56 \pm 0.01 \quad(134)$ & $1.32 \pm 0.007(74)$ & $1.07 \pm 0.06$ \\
\hline & 6-7 & $1.65 \pm 0.01 \quad(127)$ & $1.34 \pm 0.01$ & $1.07 \pm 0.01(18)$ \\
\hline & $\begin{array}{l}\text { Total of } \\
\text { litters }\end{array}$ & $1.56 \pm 0.003(584)$ & $1.26 \pm 0.006(386)$ & $1.07 \pm 0.02$ \\
\hline \multirow{5}{*}{ Group 2} & $12-13$ & $1.52 \pm 0.007(172)$ & $1.18 \pm 0.006(263)$ & $1.01 \pm 0.06(49)$ \\
\hline & $10-11$ & $1.55 \pm 0.008(100)$ & $1.24 \pm 0.01 \quad(168)$ & $1.02 \pm 0.05(30)$ \\
\hline & $8-9$ & $1.58 \pm 0.01$ & $1.31 \pm 0.008(139)$ & $1.03 \pm .0 .1$ \\
\hline & 6-7 & $1.68 \pm 0.01$ & $1.35 \pm 0.009(113)$ & $1.02 \pm 0.05(23)$ \\
\hline & $\begin{array}{l}\text { Total of } \\
\text { litters }\end{array}$ & $1.59 \pm 0.003(492)$ & $1.22 \pm 0.003(683)$ & $1.02 \pm 0.01(127)$ \\
\hline \multirow{5}{*}{ Group 3} & $12-13$ & $1.48 \pm 0.008(85)$ & $1.18 \pm 0.007(210)$ & $1.03 \pm 0.05$ \\
\hline & $10-11$ & $1.52 \pm 0.01 \quad(50)$ & $1.25 \pm 0.01 \quad(103)$ & $1.04 \pm 0.04(8)$ \\
\hline & $8-9$ & $1.55 \pm 0.01$ & $1.30 \pm 0.01 \quad(48)$ & $1.03 \pm 0.1$ \\
\hline & $6-7$ & $1.64 \pm 0.01$ & $1.35 \pm 0.01$ & $1.04 \pm 0.05$ \\
\hline & $\begin{array}{l}\text { Total of } \\
\text { fitters }\end{array}$ & $1.54 \pm 0.006$ & $1.23 \pm 0.006(397)$ & $1.04 \pm 0.03$ \\
\hline
\end{tabular}


was 15 to $16.4 \%$ lower $(P<0.001)$ than that of live prematures on the same day, and the mean body weight of the latter survivors was 19.2 to $23.2 \%$ lower $(P<0.001)$ than that of newborn mice at term. These results show that the mean body weight limit of surviving premature mice was higher than $1.07 \pm$ $0.02 \mathrm{~g}$. Statistical analysis using body weight as a function of the number of newborns per litter showed that body weight estimated $30 \mathrm{~min}$. after birth in fullterm newborns delivered vaginally on day 20 and in live premature mice removed on day 19 increased when the number of newborns per litter decreased. In contrast, the body weight of dead premature mice did not vary as a function of the number of newborns per litter; it was equal in all the litters in each group (table 3 ). Thus, the premature mice in each litter died if their body weight was equal to or lower than $1.07 \mathrm{~g}$.

\section{Breeding mortality (table 4).}

The breeding mortality of mice was characterized by a critical period occurring between birth and day 6 in both full-term newborns and prematures. There was

\section{TABLE 4}

Differences in breeding mortality from birth to day 20 after birth between full-term mice delivered spontaneously and vaginally on day 20 of pregnancy (controls) and premature mice removed by caesarean section on day 19 of pregnancy. Both groups were alive and were raised by nursing dams from $30 \mathrm{~min}$. after birth or reanimation. The dead in the litters were counted $6 \mathrm{~h}$ after birth and at $9 \mathrm{~h}$ every day from neonatal days 2 to 20 .

\begin{tabular}{|c|c|c|c|c|c|c|}
\hline \multirow{2}{*}{$\begin{array}{l}\text { Stages } \\
\text { after birth }\end{array}$} & \multicolumn{3}{|c|}{$\begin{array}{l}\text { Full-term newborns } \\
\text { (control animals) }\end{array}$} & \multicolumn{3}{|c|}{ Premature mice } \\
\hline & $\begin{array}{l}\text { Numer } \\
\text { alive }\end{array}$ & $\begin{array}{l}\text { Number } \\
\text { dead }\end{array}$ & $\begin{array}{l}\text { Mortality } \\
\text { rate }\end{array}$ & $\begin{array}{l}\text { Number } \\
\text { alive }\end{array}$ & $\begin{array}{l}\text { Number } \\
\text { dead }\end{array}$ & $\begin{array}{l}\text { Mortality } \\
\text { rate }\end{array}$ \\
\hline $\begin{array}{l}\text { From birth } \\
\text { to } 6 \mathrm{~h}\end{array}$ & $\begin{array}{l}840 \\
840\end{array}$ & 0 & 0 & $\begin{array}{l}667 \\
594\end{array}$ & 73 & 10.9 \\
\hline $\begin{array}{l}\text { From } 6 \mathrm{~h} \\
\text { to day } 2\end{array}$ & $\begin{array}{l}840 \\
815\end{array}$ & 25 & 2.9 & $\begin{array}{l}594 \\
594\end{array}$ & 0 & 0 \\
\hline $\begin{array}{l}\text { From days } 2 \\
\text { to } 3\end{array}$ & $\begin{array}{l}815 \\
800\end{array}$ & 15 & 1.8 & $\begin{array}{l}594 \\
542\end{array}$ & 52 & 8.7 \\
\hline $\begin{array}{l}\text { From days } 3 \\
\text { to } 4\end{array}$ & $\begin{array}{l}800 \\
785\end{array}$ & 15 & 1.8 & $\begin{array}{l}542 \\
536\end{array}$ & 6 & 1.1 \\
\hline $\begin{array}{l}\text { From days } 4 \\
\text { to } 5\end{array}$ & $\begin{array}{l}785 \\
770\end{array}$ & 15 & 1.9 & $\begin{array}{l}536 \\
531\end{array}$ & 5 & 0.9 \\
\hline $\begin{array}{l}\text { From days } 5 \\
\text { to } 6\end{array}$ & $\begin{array}{l}770 \\
766\end{array}$ & 4 & 0.5 & $\begin{array}{l}531 \\
525\end{array}$ & 6 & 1.1 \\
\hline $\begin{array}{l}\text { From days } 6 \\
\text { to } 7\end{array}$ & $\begin{array}{l}766 \\
766\end{array}$ & 0 & 0 & $\begin{array}{l}525 \\
525\end{array}$ & 0 & 0 \\
\hline $\begin{array}{l}\text { From days } 7 \\
\text { to } 20\end{array}$ & $\begin{array}{l}319^{*} \\
319\end{array}$ & 0 & 0 & $\begin{array}{l}289^{*} \\
289\end{array}$ & 0 & 0 \\
\hline
\end{tabular}

(*) 447 full-term newborns and 236 premature mice were killed on day 7 for other investigations. 
no mortality from day 7. During the first 6 neonatal days, the mortality rate of prematures $(21.3 \%)$ was higher than that of newborns at term $(8.7 \%)$. As the mortality rate of prematures was equal to that of newborns at term from neonatal days 4 to 6 , mortality due to prematurity appeared only during the first 3 neonatal days; the true breeding mortality rate of prematures was $14.0 \%$ from birth to day 3 . The statistics of table 4 show that mortality between birth and day 2 began only $6 \mathrm{~h}$ after birth in control animals, and occurred only during the first 6 neonatal hours in prematures. There was no relationship between mortality rate and the number of newborns per litter; dead neonates were distributed equally in litters of 6 to 13 newborns.

Finally, breeding mortality in the mouse due to prematurity was of two types: (1) primary neonatal mortality $(10.9 \%)$ occurring from the end of reanimation to 6 neonatal hours and (2) secondary neonatal mortality $(6.9 \%)$ appearing between $9 \mathrm{~h}$ on day 2 and $9 \mathrm{~h}$ on day 3 .

\section{Discussion.}

The present experiments show that, in spite of mortality, many premature mice obtained by caesarean section survive.

There are two types of mortality in premature mice : mortality at birth occurring during reanimation and breeding mortality. Because of the basic relationship between birth weight, gestational age and mortality rate in prematures, it is imperative to take into consideration the joint effect of birth weight and gestational age when examining neonatal mortality.

1. Mortality at birth. - Our statistics show that the chances of premature mice surviving at birth depends on both gestational age and birth weight. Premature mice cannot survive after caesarean section, in spite of reanimation, if their gestational age is less than 19 days, although the term is 20 days in this species. The mortality rate in 18-day old foetuses at reanimation is $100 \%$ whereas it is only $13.2 \%$ in 19-day old foetuses. The mean birth weight of 18-day old dead foetuses and 19-day old dead foetuses is about 41 and $33 \%$ less, respectively, than that of full-term newborns. Since the mean birth weight of surviving premature mice is about $20 \%$ less than that of full-term newborns, the limit of mean birth weight for the survival of the former ranges between 67 and $80 \%$ of that of full-term newborn mice. The present experiments have demonstrated that the mortality of 19-day old premature mice does not depend on the number of newborns per litter. Mortality occurred in all litters when foetal body weight was equal to or less than $1.07 \mathrm{~g}$, and foetuses weighing less than that were found in litters of 6 to 13 newborns. Compared to other species, the limit of gestational age and birth weight for survival is high in premature mice. The survival rate in premature rats is $52 \%$ when they are removed by caesarean section on day 20 of gestation, term being 21 days (Weinhold et al., 1980). In swine, the number of stillborn piglets is significantly higher when gestation lasts less than 112 days, although maturity is reached at 113-116 days (Aumaitre et al., 1979). The birth 
weight in full-term newborn sheep varies between 1500 and $5000 \mathrm{~g}$; survival rate is $70 \%$ for birth weights between 1500 and $2000 \mathrm{~g}$ and only $10 \%$ for those of less than $1500 \mathrm{~g}$ (Houssin and Brelurut, 1980). The viability limit is high in primates. Premature human babies are viable from week 28 of pregnancy, although pregnancy lasts about 40-42 weeks, and they can survive when body weight is even less than $1500 \mathrm{~g}$, although the mean birth weight of full-term newborns is about $3500 \mathrm{~g}$. Premature rhesus monkey newborns survive from day 130 of gestation, although gestation lasts 175 days, and the limit of birth weight for survival is $63 \%$ of that of full-term newborns (Shaughnessy et al., 1978). Nevertheless, it is difficult to compare mice with primates because of the difference in the number of newborns per litter and also because the premature mice in our experiments were removed by caesarean section, while the human prematures were delivered vaginally.

A lack of lung surfactant is certainly a factor in the death of 18-day old premature mice removed by caesarean section. Indeed, autopsy of all those that died during reanimation showed complete atelectasis of the lungs and it is known that lung surfactant is present only after day 18 of gestation in mouse foetuses (Buckingham and Avery, 1962). The lungs of 19-day old premature mice that died during reanimation were also atelectatic, and it is likely that a lack of lung surfactant was also a factor since the weight of these foetuses was low like that of 18-day old premature mice.

2. Breeding mortality. - The breeding mortality of premature mice was determined by comparing 19-day old premature mice raised from birth to day 20 by nursing dams to full-term newborns also raised by nursing mothers. The nursing mothers were delivered vaginally at the same time as the mothers of premature mice and full-term newborns. However, in our experiment, neonate adoption was homogeneous since for the statistical study we used only litters from nursing mothers that had regularly suckled neonates from birth to day 20 . The breeding mortality of premature mice was not related to the number of neonates per litter since the dead neonates were distributed equally in all litters. The relationship between breeding mortality and neonate body weight is not known because we could not weigh live neonates during neonatal development for fear that the dams would reject the neonates. Therefore, it is difficult to compare the mice with other species. In swine, for example, newborn survival rate depends on both the birth weight and the length of gestation : survival rate is minimal for premature animals born before 112 days and for full-term animals having a low birth weight (Aumaitre et al., 1979) ; $50 \%$ of piglets with a birth weight of less than $900 \mathrm{~g}$ die over the first neonatal week (Hartsock et al., 1977), although mean birth weight is about $1200 \mathrm{~g}$.

Breeding mortality in premature mice occurs only during the first 3 neonatal days. It is interesting that while this mortality in premature humans is also high during the first 3 neonatal days, it remains that way from neonatal days 3 to 28 , in contrast to premature mice (Loctin, 1980).

Statistics in the present study establish that breeding mortality in premature mice occurs during the first 6 neonatal hours (primary neonatal mortality) and 
then between days 2 and 3 (secondary neonatal mortality). Several factors are involved in this mortality and the following probably affect primary neonatal mortality : (1) lack of surfactant : statistics on 242 19-day old live premature mice killed after reanimation show that $5.7 \%$ of them had atelectasis of the lungs ; (2) milk sucking disorders : milk was found in the stomach of $92 \%$ of full-term newborns killed $6 \mathrm{~h}$ after birth, whereas it was found in only $50 \%$ of premature mice ; (3) thermoregulation disorders : heat production was deficient in brown fat due to inadequate availability of lipid (Bertin et al., 1982) ; (4) insufficient response of aldosterone secretion to high loss of sodium and water due to kidney immaturity in the first 6 neonatal hours, inducing stimulation of aldosterone secretion in surviving premature mice (Loctin and Delost, 1982) ; (5) insufficient response of corticosterone secretion to reanimation stress, inducing a peak of plasma corticosterone in surviving premature mice $6 \mathrm{~h}$ after birth (Loctin, 1980).

All these factors (except surfactant deficiency) and many more are probably involved in secondary neonatal mortality. Our results deserve further investigation of the factors responsible for the mortality of premature mice, particularly the role of the adrenal cortex.

Reçu en juillet 1982.

Accepté en novembre 1982.

Acknowledgements. - This research program was supported by a grant from the CNRS. The authors wish to thank Mrs. Tournaire for technical assistance.

Résumé. Mortalité du prématuré de souris à la naissance et au cours du développement néonatal.

L'étude statistique de la mortalité à la naissance et au cours du développement néonatal a été réalisée sur environ 2500 prématurés de Souris. Les prématurés ont été obtenus par césarienne et réanimés pendant $30 \mathrm{~min}$. ; les prématurés survivant après la réanimation ont été élevés, de la naissance au $20^{\circ}$ jour, de même que les nouveau-nés à terme délivrés spontanément par voie basse au $20^{\mathrm{e}}$ jour de gestation (animaux de contrôle), par des nourrices qui avaient mis bas au même moment. La mortalité du prématuré et du nouveau-né à terme a été comptée à la naissance immédiatement après la césarienne et $30 \mathrm{~min}$. après la réanimation ou la parturition, à $6 \mathrm{~h}$ après la naissance et à $9 \mathrm{~h}$ chaque jour du $2^{\mathrm{e}}$ au $20^{\mathrm{e}}$ jour après la naissance. La césarienne n'est responsable d'aucune mortalité. Les chances de survie du prématuré de Souris dépendent à la naissance à la fois de l'âge gestationnel et du poids de naissance. Le prématuré de Souris ne peut pas survivre si son âge gestationnel est inférieur au $19^{\mathrm{e}}$ jour de gestation et si son poids de naissance est inférieur de $33 \%$ par rapport au poids du nouveau-né à terme. II n'y a pas de relation entre la mortalité et le nombre de nouveau-nés par portée. II existe deux sortes de mortalité chez le prématuré de Souris : une mortalité de réanimation évaluée à $13 \%$ et une mortalité d'élevage qui apparaît seulement au cours des trois premiers jours de la vie. Cette dernière peut être subdivisée en une mortalité néonatale primaire, qui se produit entre la fin de la réanimation et la $6^{\mathrm{e}}$ heure de vie et qui est de l'ordre de $10,9 \%$ et une mortalité néonatale secondaire qui réapparaît entre le $2^{\mathrm{e}}$ jour et le $3^{\mathrm{e}}$ jour de la vie et qui est de l'ordre de $6,9 \%$. Le rôle de certains facteurs dans la mortalité est envisagé. 


\section{References}

AUMAITRE B., DEGLAIRE B., LEBOST J., 1979. Prématurité de la mise-bas chez la truie et signification du poids à la naissance du porcelet. Ann. Biol. anim. Bioch. Biophys., 19, 267-275.

BERTIN R., LOCTIN J., BEAUVALLET M., PORTET R., DELOST P., 1982. Neonatal development of brown adipose tissue in premature mice. Experientia (in press).

BUCKINGHAM S., AVERY M. A., 1962. Time of appearance of lung surfactant in the foetal mouse. Nature, 193, 688-689.

DALLE M., GIRY J., GAY M., DELOST P., 1978. Perinatal changes in plasma and adrenal corticosterone and aldosterone concentrations in the mouse. $J$. Endocr., 76, 303-309.

DIGIACOMO R., SHAUGHNESSY P., 1972. Estimation of gestational age and birth weight in the rhesus monkey (Macaca mulatta). Amer. J. Obstet. Gynec., 12, 619-628.

FUCHS F., 1977. Prevention of prematurity. Amer. J. Obstet. Gynec., 126, 809-820.

HARTSOCK T. G., GRAVES H. B., BAUMGARDT B. R., 1977. Agonistic behaviour and the nursing order in suckling piglets : relationships with survival growth and body composition. J. anim. Sci., 44, 320-330.

HATT J. J., FLUSIN M. F., CHAVANNE J., 1972. L'élevage et l'avenir des prématurés de poids égal ou inférieur à $1250 \mathrm{~g}$. Ann. Pediat., 19, 67-71.

HIRD D., HENRICKSON R., HENDRICKS A., 1975. Infant mortality in Macaca mulatta : neonatal and postnatal mortality at the California Primate Research Center. J. Med. Primatol, 4, 8-22.

HOUSSIN Y., BRELURUT A., 1980. Mortalité avant sevrage d'agneaux de différents génotypes dans un troupeau en conduite intensive. Bull. techn. C.R.Z.V., Theix, I.N.R.A., 40 , $5-12$.

LAUGIER J., GOLD F., 1978. Abrégé de Néonatalogie, Masson et Cie, Paris, 262 pp.

LOCTIN J., 1980. Obtention, mortalité, croissance et fonction minéralocorticö̈de du prématuré expérimental de Souris. Thèse $3^{e}$ Cycle, Clermont-Ferrand, France, $246 \mathrm{pp}$.

LOCTIN J., DELOST P., 1982. Plasma and adrenal aldosterone levels in premature mice at birth and during neonatal development. Steroids (in press).

LUBCHENCO L. O., SEARLS D. T., BRAZIE J. V., 1972. Neonatal mortality rate : relationship to birth weight and gestational age. J. Pediat., 81, 814-822.

N'KOUMOUN S., 1978. Le nouveau-né de faible poids de naissance (1500-2000 g). Devenir immédiat et à moyen terme. Th. Doct. Méd., Bordeaux, France, $125 \mathrm{pp}$.

PAPIERNIK E., 1977. L'accouchement prématuré et sa prévention. Arch. franç. Péd., 34. $488-491$.

PRICE R., ANVER M., GARCIA F., 1972. Simian neonatality. I. Gestational maturity and extrauterine viability. Vet. Pathol., 9, 301-309.

ROSSIER A., 1969. Prématurité. Encyclopédie Médicochirurgicale, Paris, Pédiatrie 1re enfance, 4002, 510, 1-16.

RUSH R. W., DAVEY D. A., SEGALL M. L., 1978. The effect of preterm delivery on perinatal mortality. Brit. J. Obstet. Gynaec., 85, 806-811.

SENECAL J., BUESTEL M. L., DELAHAYE M., VONGSAVANTHONG S., LETY A., 1977. Etude de la mortalité néonatale précoce dans le département de l'llle-et-Vilaine en 1972, 1973 et 1974. Ann. Pédiat., 24, 97-107.

SHAUGHNESSY P. W., DIGIACOMO R. F., MARTIN D. P., VALERIO D. A., 1978. Prematurity and perinatal mortality in the rhesus (Macaca mulatta) : relationship to birth weight and gestational age. Biol. Neonate, 34, 129-145.

VARANGOT J., PARENT B., CHARLES R., 1975. La mortalité périnatale à Port-Royal (19621971). J. Gynec. Obstet. Biol. Rep., 4, 357-371.

WEINHOLD P. A., QUADE M. M., BROZOWSKI T. B., FELDMAN D. A., 1980. Increased synthesis of phosphatidyl choline by rat lung following premature birth. Biochim. biophys. Acta, 617, 76-84. 